\title{
Water shortage pits man against nature
}

\section{San Francisco}

Heavy rains and snows fell in California last week, bringing a welcome respite to this state that has now suffered five years of drought. As welcome as it was, however, the precipitation will not go very far to restore the withered landscapes, dry reservoirs and fallow farmland that have become all too common in California.

In the face of nature's adversity, engineers and planners are now turning to scientific and technological solutions to the water shortage. Instead of praying for rain, they are considering such options as seeding clouds over the Sierra Nevada mountains, desalting Pacific Ocean seawater and piping fresh water thousands of miles from Alaska.

Although it has rained little in California in recent years, the drought is not due to a lack of storms, says Tom Henderson, president of Atmospherics, Inc., a cloud-seeding company in Fresno.

The drought years have actually produced 80 per cent of the number of storms of normal years, he says. Instead, the problem is that the storms in wet years were generally taller, thicker, longer-lasting and much higher in liquid water content than those in the drought years. So, while some regions have seeded clouds for years to increase rainfall, this winter several more communities have turned to various cloud-seeding techniques to enhance the weaker storm systems.

Monterey County is paying about $\$ 130,000$ to send airplanes into every cloud that has the potential to produce rain for the area this season. The planes release tiny crystals of silver iodide which, at appropriate temperatures and sites within the cloud, act as nuclei for ice crystals, which later become rain or sleet or snow. Monterey County dis- trict meteorologist John Stremel finds the initial results of the cloud-seeding programme "very encouraging", although actual increases will not be calculated until the end of the season.

Over the high hills of Santa Barbara, cloud seeding has led to a 25 per cent increase in rainfall, with rain falling earlier during storms and more intensely. Most efforts do less well, Henderson says - the process typically yields a $5-15$ per cent increase in annual precipitation.

Silver iodide, used in 95 per cent of all cloud-seeding efforts worldwide, is the material of choice for rain-making, but researchers are testing a variety of other materials. Dry ice, for example, can be used when cloud-top temperatures are between $-4{ }^{\circ} \mathrm{C}$ and $-5^{\circ} \mathrm{C}$, warmer than the conditions for silver iodide. And Atmospherics is experimenting with different organic compounds that modify the seeding agents for use in different cloud conditions.

Henderson has also seeded a few clouds with the bacterium Pseudomonas syringae, which is usually found on plant leaves, where it nucleates ice crystals. Atmospherics scientists are still optimizing its use in laboratory tests, but they have found it can form crystals at the relatively high temperature of $-0.5^{\circ} \mathrm{C}$.

In the Plumas National Forest, the state Department of Water Resources and the US Forest Service are developing an experimental ground-based cloud-seeding programme that uses propane to trigger precipitation. Propane has been used by the US Air Force to clear fog at airports, but this project is expected to mark its first use in cloud-seeding. Courtland Bennett of the US Forest Service says the plan calls for ten seeding stations on mountain ridges over Feather River to release liquid propane into the atmosphere at cloud level in the hope of generating additional runoff into reservoirs of the State Water Project.

Some California cities have begun to look toward a source of almost unlimited water: the sea. Although desalination plants have operated for years in Middle Eastern countries, and even in Florida in the United States, they have traditionally been considered too expensive for use in California because they require huge amounts of en-

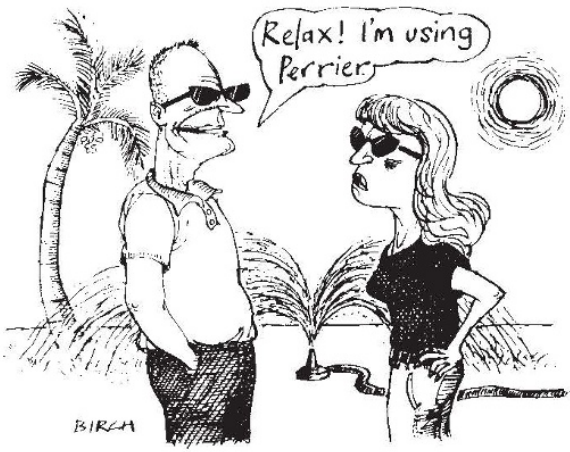

ergy.

But the city of Santa Barbara has decided to tolerate the high cost in return for a guaranteed water supply. In that central coast city, where the two main water reservoirs are just 12 and 14 per cent full, officials say construction of a desalination plant will begin by midsummer. The city currently delivers water to its customers for $\$ 200$ per acre-foot, but it will pay contractors $\$ 1,900$ per acrefoot for the desalted water when it becomes available in a year. (An acre-foot of water is 326,000 gallons, or enough to supply a suburban family of five for a year.)

Desalination plans are also under scrutiny

\section{Drought threatens Californian bird populations}

California's drought is putting at risk several populations of the state's endangered and threatened species, including a pioneering pair of bald eagles and several types of fish.

At Lake Cachuma in central California, US Fish and Wildlife Service biologists are worried about a breeding pair of endangered bald eagles. Although this part of the state was once a common breeding ground for the eagles, the birds retreated north in the 1950s, and it was only two years ago that this pair became the first to recolonize the Lake Cachuma territory. But the lake, which supplies water to Santa Barbara, is just 14 per cent full, and biologists fear that if it loses its fish populations, it will also lose the pair of resident eagles as well as 15 other eagles that winter there before returning to their northern nesting grounds.

With only 2,000 breeding pairs of eagles in the continental United States, it is important to encourage the raptors to colonize many areas so that a local disaster does not destroy the species, says Robert Mesta of the Fish and Wildlife Service. The Lake Cachuma pair "represent the seed of a Southern California population", he says, and their progeny will probably return to the lake.

Further north, in the Sacramento River delta, winter-run chinook salmon are in danger. For a number of reasons, the salmon population, which runs up the Sacramento River to spawn, has been diminishing for several years and last year reached a record low of 441 . Now biologists are worried that after upstream water is diverted by federal water projects to farms and cities, the river will be too warm for the fish. Water temperatures over $56^{\circ} \mathrm{F}\left(13.3^{\circ} \mathrm{C}\right)$ are deleterious to the salmon, and temperatures over 60 ${ }^{\circ} \mathrm{F}\left(15.5^{\circ} \mathrm{C}\right)$ are lethal.

Officials with the federal Central Valley Project are now studying ways to change water delivery plans or lower the river- water temperature to spare the winterrun salmon. The species is protected under the Endangered Species Act.

But many other species of fish are also in danger, and are not yet covered by the Endangered Species Act, says Peter Moyle, professor of wildlife and fisheries biology at the University of California at Davis. Moyle recently completed a survey of all the native fishes in the state and found that of the 113 species, 74 were in need of special protection. Six of those species had become extinct since 1957 , and 16 were formally listed as endangered. Most of the damage had been done by water diversions and the introduction of predatory game fish, but for some species the drought could be the final straw. Moyle predicts that with another year of drought the state could add delta smelt, coho salmon and spring-run chinook saimon to the list of species that have disappeared from California waters. 